\title{
SISTEM INFORMASI PERSEDIAAN OLI DENGAN METODE ROP DI CV. SUMBER LUMAS SEMARANG
}

\author{
Suwardi, Danang Danang \\ STEKOM Semarang, Program Studi D4 Komputerisasi Akuntansi \\ didikmale@yahoo.com \\ STEKOM Semarang, Program Studi D3 Teknik Elektro \\ danang@stekom.ac.id
}

\begin{abstract}
Inventory is one component of company assets which is very important in supporting the continuity of operational activities of trading companies. The process of inventory mutation, makes business owners required to be able to provide accurate and relevant information about inventory. This information can be generated from the use of a merchandise inventory information system which can help business owners to know the processes related to the availability of these merchandises.

To monitor the process of oil transfer and oil availability on the CV. Sumber Lumas Semarang, business owners still use manual data input by using Microsoft Excel applications and hand-written stock cards. The manual use of this system causes several obstacles, including: frequent occurrences of oil inventory balances due to human error factors in recording items on stock cards, over-stock/stock out of oil inventory in warehouses and late oil inventory reporting due to data from stock cards moved into the Microsoft Excel format every month that requires precision and a lot of time. This makes the oil inventory report is not up to date.

Observed at the problems faced today, CV. Sumber Lumas Semarang needs a system which can overcome the problems of merchandise inventory record and can produce relevant and accurate merchandise inventory information.
\end{abstract}

Keywords: inventory information system, merchandise inventory, ROP

\section{PENDAHULUAN}

Bagi pemilik usaha yang bergerak di bidang perdagangan, persediaan barang dagang merupakan hal yang sangat penting bagi keberlangsungan usahanya. Persediaan merupakan salah satu aktiva perusahaan yang dapat diproses dalam sebuah siklus produksi, kemudian dijual untuk memperoleh keuntungan bagi perusahaan, maupun dikonsumsi sendiri dalam siklus normal perusahaan. Persediaan barang dagang dapat diperoleh dari distributor lain atau dipesan langsung dari pusat perusahaan melalui proses pembelian. Persediaan tersebut kemudian ditampung di dalam gudang dan nantinya akan disalurkan kembali kepada para konsumen/masyarakat melalui proses penjualan.

Adanya proses pemasukan dan pengeluaran persediaan, membuat pemilik usaha dituntut untuk dapat menyediakan informasi tentang persediaan yang akurat dan relevan. Informasi tersebut dapat dihasilkan dari sebuah sistem informasi persediaan barang dagang yang dapat membantu pemilik usaha untuk mengetahui proses yang berkaitan dengan ketersediaan barang dagang tersebut.

CV. Sumber Lumas Semarang merupakan distributor oli yang sudah berdiri selama 39 tahun. Usaha yang berlokasi di Jl. MT. Haryono no. 20 Semarang ini tidak hanya melayani penjualan oli saja, akan tetapi juga melayani jasa ganti oli dan filter oli. Untuk menjalankan kegiatan usahanya, CV. Sumber Lumas Semarang memiliki 27 orang karyawan hingga sekarang ini.

Untuk memantau ketersediaan barang dagang di CV. Sumber Lumas Semarang, pemilik usaha masih menggunakan penginputan data secara manual dengan bantuan aplikasi Microsoft Excel dan kartu stok yang ditulis tangan.Penggunaan sistem secara manual ini menyebabkan beberapa kendala yang dialami oleh pihak manajemen dalam mengelola manajemen persediaan oli. Beberapa kendala tersebut antara lain:

1. Sering terjadinya selisih saldo persediaan oli karena kesalahan pencatatan (human error) dalam proses mutasi barang di kartu stok.

2. Sering terjadinya over stock/stock out persediaan oli di gudang

3. Terlambatnya pelaporan persediaan oli karena data dari kartu stok dipindahkan ke dalam format Microsoft Excel setiap bulannya yang membutuhkan ketelitian dan banyak waktu. Hal ini membuat laporan persediaan oli menjadi tidak up to date. 
Dengan melihat permasalahan yang dihadapi saat ini, CV. Sumber Lumas Semarang memerlukan sebuah sistem yang dapat mengatasi permasalahan pencatatan persediaan barang dagang dan dapat menghasilkan informasi persediaan barang dagang yang relevan dan akurat.

\section{RUMUSAN MASALAH}

a. Bagaimanakah merancang sistem persediaan oli untuk mengoptimalkan biaya persediaan dengan metode ROP?

b. Bagaimanakah merancang sistem persediaan oli yang dapat membantu mengelola manajemen persediaan oli di CV. Sumber Lumas Semarang?

c. Bagaimanakah merancang sistem persediaan oli agar dapat menghasilkan laporan persediaan oli yang akurat?

\section{TUJUAN PENELITIAN}

Tujuan penelitian ini adalah:

a. Membantu manajemen CV. Sumber Lumas Semarang dalam menentukan kapan dan berapa jumlah oli yang harus dipesan dan tersedia di gudang

b. Membantu manajemen CV. Sumber Lumas Semarang dalam mengelola persediaan oli, mulai dari proses pengadaan, pembelian, penyimpanan, dan penjualan.

c. Membantu manajemen CV. Sumber Lumas Semarang dalam menyediakan laporan persediaan oli yang akurat untuk pengambilan keputusan.

\section{KAJIAN PUSTAKA}

\section{a. Sistem}

Sistem merupakan sekumpulan dari elemen yang berinteraksi untuk mencapai suatu tujuan tertentu (Jogiyanto, 2001).

b. Sistem Informasi

Krismiaji (2015) menyatakan bahwa sistem informasi merupakan beberapa cara yang telah diorganisasi untuk mengumpulkan, memasukkan, mengolah, dan menyimpan data. Cara inilah yang diorganisasi untuk menyimpan, mengelola, mengendalikan, dan melaporkan sedemikian rupa sehingga organisasi dapat mencapai tujuannya.

\section{c. Persediaan}

Mulyadi (2001) menjelaskan bahwa persediaan dapat dibedakan menjadi beberapa jenis, yaitu: persediaan barang jadi, persediaan barang dalam proses, persediaan bahan baku, persediaan bahan penolong, persediaan bahan habis pabrik, serta persediaan suku cadang.

d. Sistem Informasi Persediaan Barang Dagang
Sistem informasi persediaan barang dagang merupakan sebuah sistem informasi yang mencakup mulai dari proses pengadaan, pembelian, penyimpanan, hingga ke penjualan barang dagang. Sistem informasi ini membantu pihak manajemen dalam memantau kontinuitas persediaan sehingga kegiatan operasional dapat berjalan dengan baik.

e. Metode ROP (Reorder Point)

Dalam sistem informasi persediaan, ada hal penting yang perlu diperhatikan, yaitu bagaimana kontinuitas persediaan dapat berjalan dengan baik.Oleh karena itu, diambil metode yang dapat menghitung menghitung waktu yang paling ideal dalam melakukan pemesanan kembali sementara persediaan yang ada di gudang masih dalam batas-batas ekonomis.Dalam hal ini, penelitian Ramdhany dan Kurnia (2016) menggunakan metode ROP.

Menurut Stevenson dan Chuong (2014), ROP atau titik pemesanan kembali terjadi ketika kuantitas ditangan berada dalam jumlah minimum yang telah ditentukan sebelumnya. Jumlah tersebut biasanya meliputi perkiraan permintaan selama waktu tunggu dan jumlah cadangan persediaan, yang berfungsi untuk mengurangi probabilitas terjadinya kehabisan persediaan selama waktu tunggu.

Terdapat empat determinan dari kuantitas titik pemesanan kembali, yaitu:

a. Tingkat permintaan

b. Waktu tunggu

c. Sejauh mana variabilitas permintaan dan/atau waktu tunggu

d. Derajat resiko kehabisan persediaan yang dapat diterima oleh manajemen.

Jika permintaan dan waktu tunggu keduanya konstan, titik pemesanan kembalinya didapat rumus:

Keterangan :

$$
\text { ROP }=\mathrm{d} \times \mathbf{L T}
$$

$\mathrm{d}=$ Tingkat permintaan (unit per hari atau per minggu)

LT = Waktu tunggu dalam hari atau minggu 
Ketika terdapat variabilitas dalam permintaan atau waktu tunggu, perlu menyimpan persediaan tambahan yang disebut persediaan aman/safety stock (Gambar 1a), untuk mengurangi kehabisan selama waktu tunggu. ROP kemudian meningkat sebesar jumlah persediaan aman:

ROP $=$ Perkiraan permintaan
selama waktu tunggu +
Persediaan aman(safety stock)

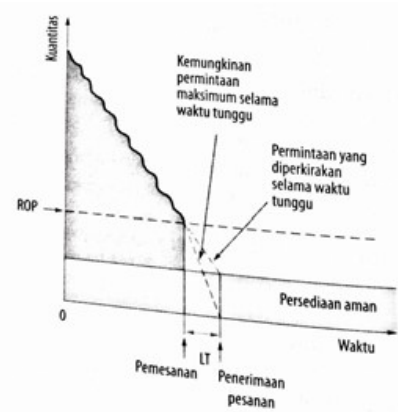

Gambar 1a. Persediaan Aman (Safety Stock)

\section{PEMBAHASAN PENELITIAN}

Sistem informasi persediaan oli yang dikembangkan dengan bahasa pemograman Clipper dan FoxBase ini mempunyai tampilan antar muka sebagai berikut:

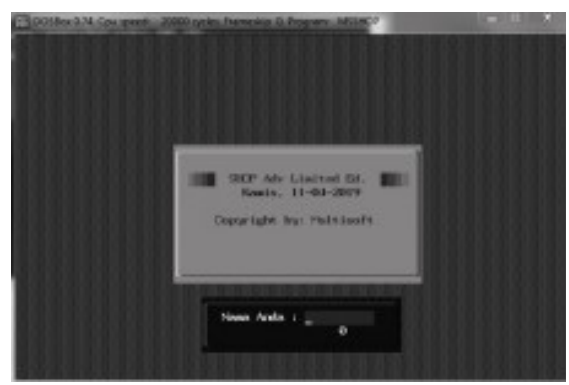

Gambar 1. Tampilan Awal Program

Gambar 1 menunjukkan tampilan awal program sistem persediaan. Pada tampilan awal ini, kita dapat mengetikkan username dan password untuk dapat login ke dalam program. Setelah login, maka tampilan program memperlihatkan menu-menu yang terdapat di dalam program sistem persediaan (Gambar 2). Menu dalam program ini meliputi Menu Master, Menu Transaksi, Menu Laporan, dan Menu Peralatan.

\section{a. Menu Master}

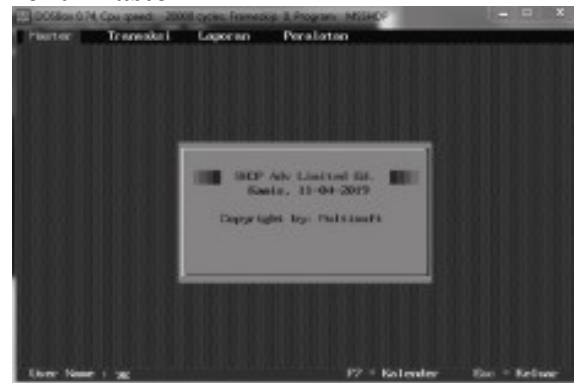

Gambar 2. Tampilan Menu Program

Untuk menu Master, terdapat 3 sub menu (Gambar 3), yaitu Supplier, Barang, dan Customer. Sub Menu Supplier merupakan form untuk menambah, mengedit, mencari maupun menghapus nama supplier (Gambar 4).

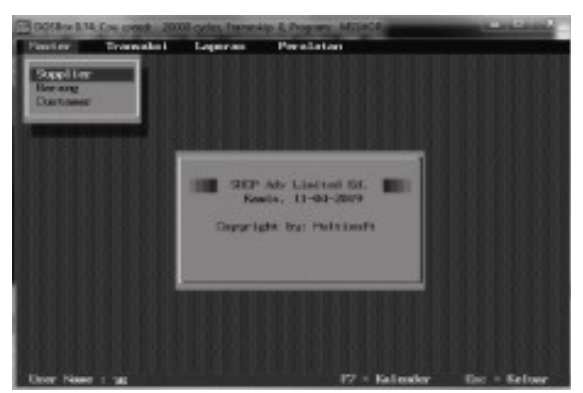

Gambar 3. Tampilan Menu Master

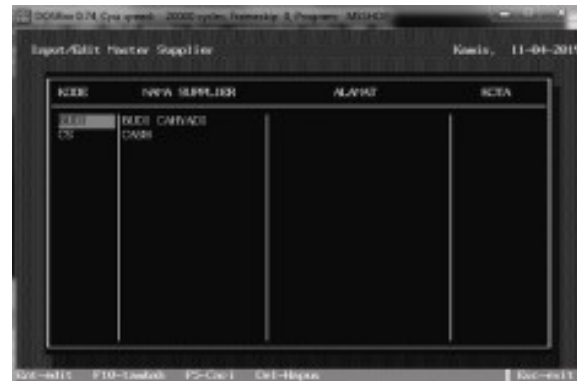

Gambar 4. Tampilan Sub Menu Supplier

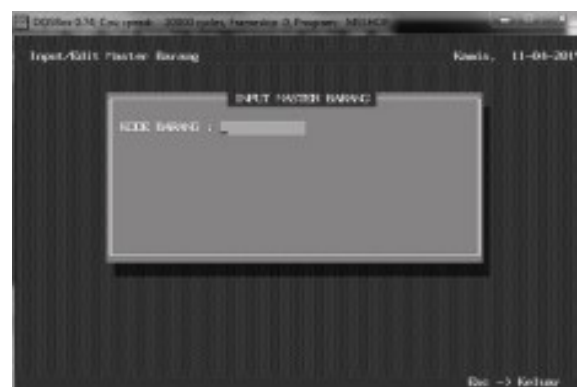

Gambar 5. Tampilan Sub Menu Barang 


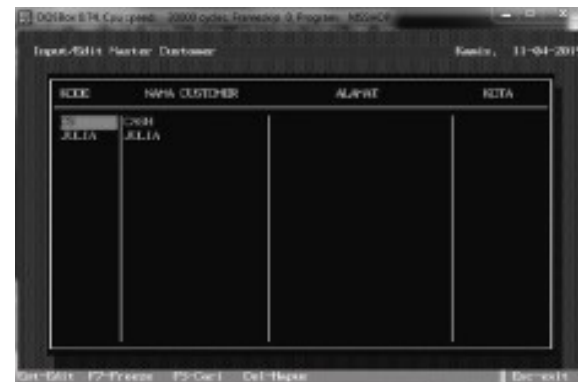

Gambar 6. Tampilan Sub Menu Customer

Gambar 5 dan Gambar 6 memperlihatkan tampilan sub menu Barang dan Customer di mana sub menu ini digunakan untuk menambah, mengedit, mencari maupun menghapus nama barang dagangan dan konsumen.

b. Menu Transaksi

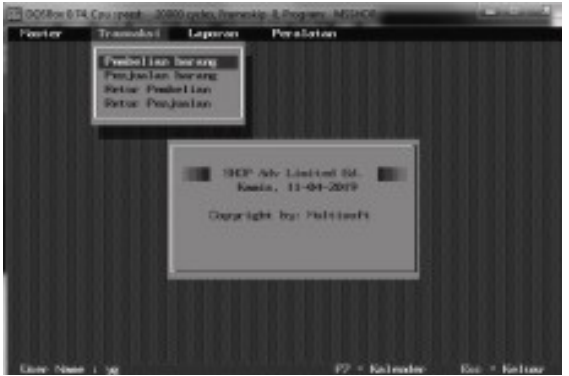

Gambar 7. Tampilan Menu Transaksi

Menu Transaksi (Gambar 7) berisi sub menu Pembelian Barang (Gambar 8), Penjualan Barang (Gambar 9), Retur Pembelian (Gambar 10), maupun Retur Penjualan (Gambar 11). Untuk setiap form dalam sub menu Transaksi memudahkan pengguna untuk menambah, mengedit, mencari data, maupun mencari info barang dagangan. Sementara untuk sub menu Pembelian Barang Dagangan, dilengkapi dengan info tanggal jatuh tempo.

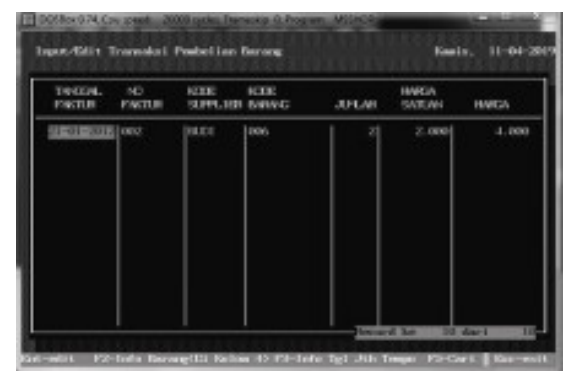

Gambar 8. Tampilan Sub Menu Transaksi Pembelian Barang

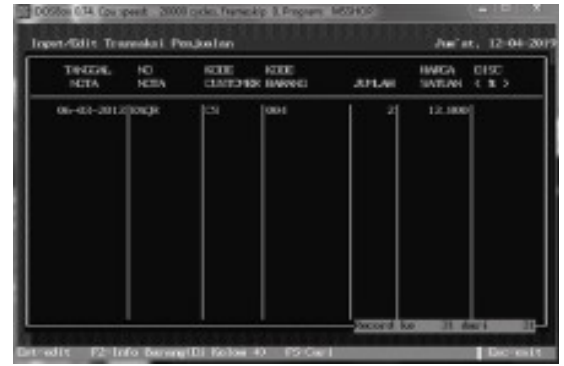

Gambar 9. Tampilan Sub Menu Transaksi Penjualan Barang

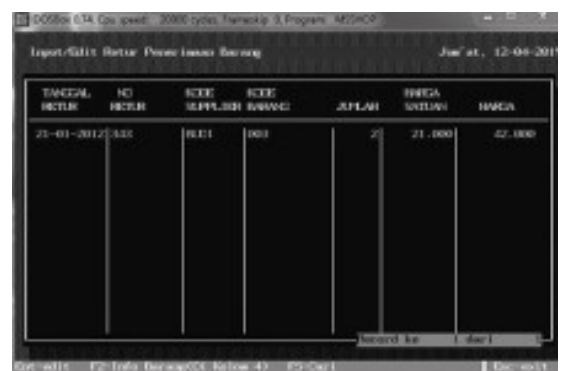

Gambar 10. Tampilan Sub Menu Transaksi Retur Pembelian Barang Dagangan

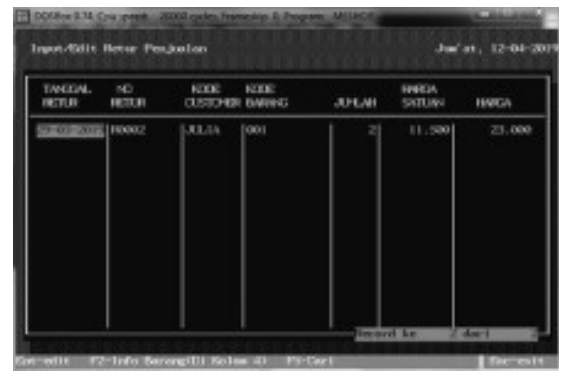

Gambar 11. Tampilan Sub Menu Transaksi Retur Penjualan Barang Dagangan

c. Menu Laporan

Menu Laporan berisi Sub Menu Laporan Daftar Harga Barang, Laporan Persediaan, Laporan Mutasi Barang, Laporan Pembelian dan Penjualan Barang, Laporan Retur Pembelian dan Penjualan, serta Laporan Daftar Supplier dan Customer.

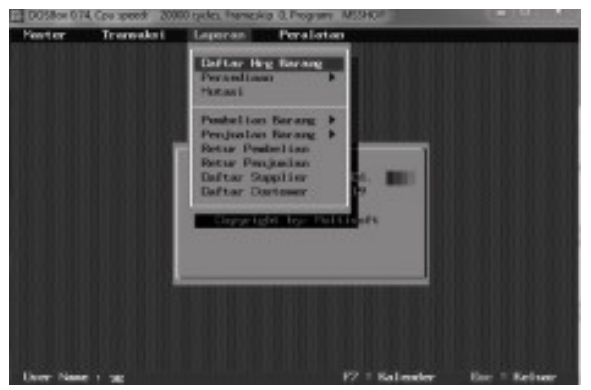

Gambar 12. Tampilan Menu Laporan

Untuk proses mencetak Laporan Daftar Barang (Gambar 13), pengguna dapat memilih apakah akan mencetak laporan secara lengkap, tanpa HPP, atau tanpa harga jual. 


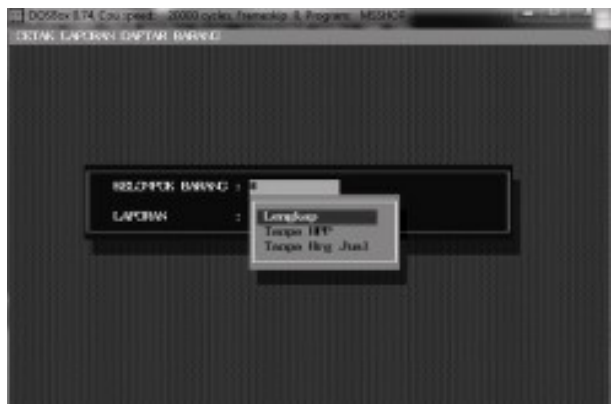

Gambar 13. Tampilan Sub Menu Cetak Laporan Daftar Barang

Apabila pengguna memilih mencetak laporan secara lengkap (Gambar 14), maka tampilan laporan sebagai berikut:

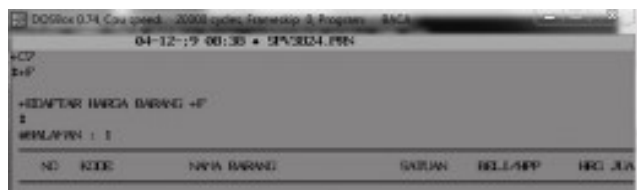

Gambar 14. Tampilan Laporan Daftar Barang

Untuk mencetak Laporan Persediaan Barang, pengguna dapat memilih apakah akan mencetak semua barang dagangan atau hanya barang dagangan tertentu saja (Gambar 15 dan Gambar 16). Gambar 17 memperlihatkan Laporan Persediaan Barang yang dicetak secara lengkap untuk semua barang dagangan.

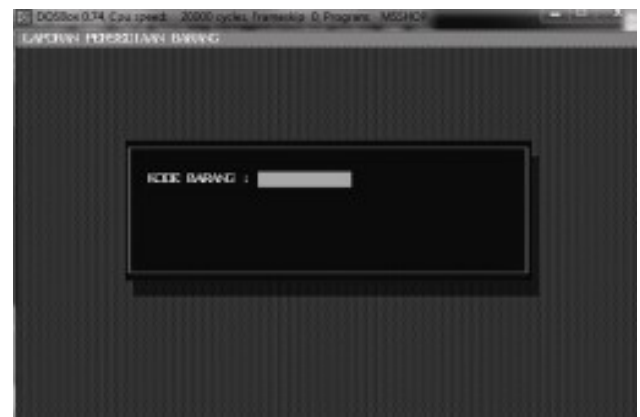

Gambar 15. Tampilan Cetak Laporan Persediaan Barang (Barang Tertentu)

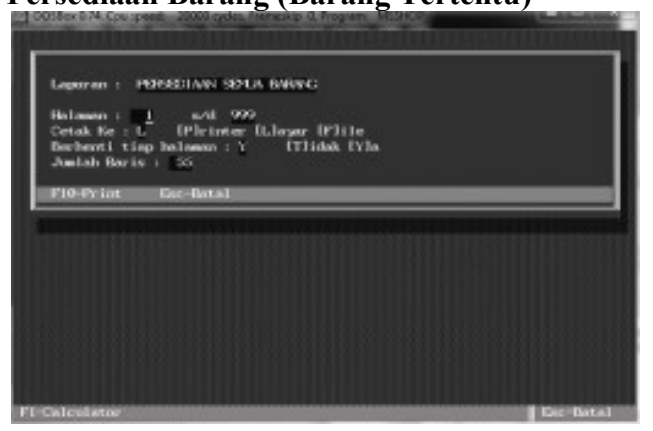

Gambar 16. Tampilan Cetak Laporan Persediaan Barang (Semua Barang)

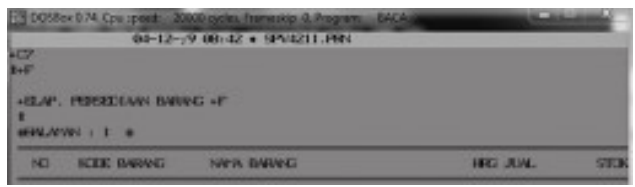

Gambar 17. Laporan Persediaan Barang (Semua Barang)

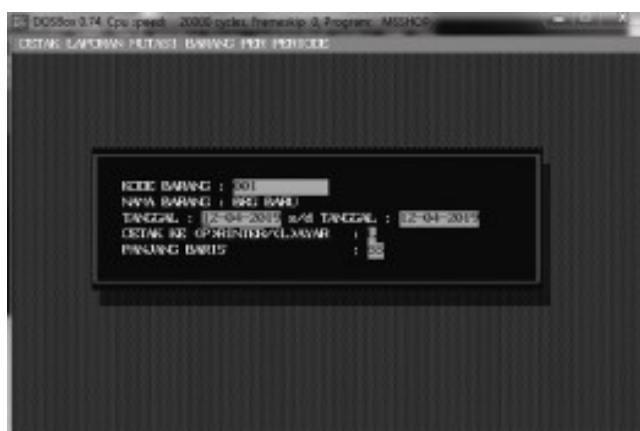

Gambar 18. Tampilan Cetak Laporan Mutasi Barang Per Periode

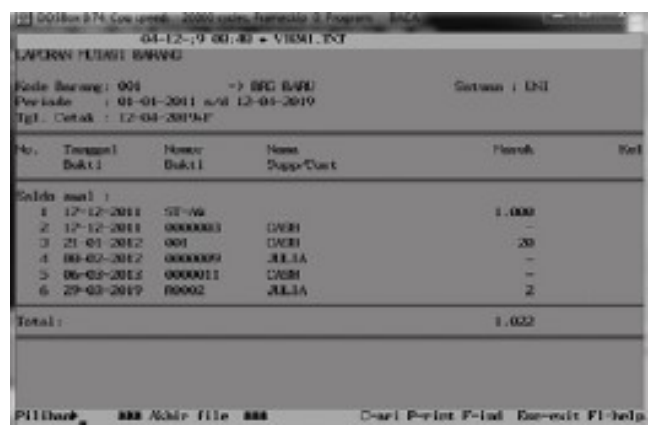

Gambar 19. Laporan Mutasi Barang Per Periode

Selain itu, pengguna sistem juga dapat mencetak Laporan Mutasi Barang Per Periode berdasarkan masing-masing kode barang (Gambar 18). Laporan ini memberikan informasi secara detail tentang kondisi keluar masuknya barang dagangan selama periode tertentu (Gambar 19).

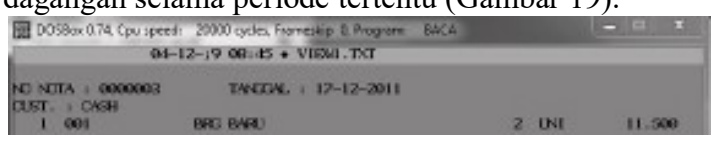

Gambar 20. Laporan Penjualan Barang Per Periode

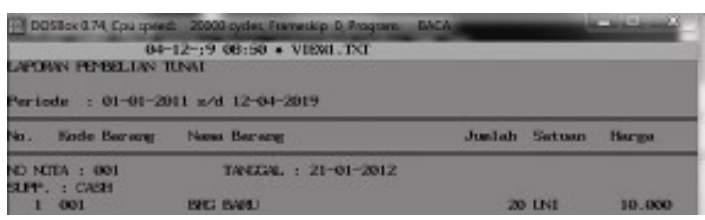

Gambar 21. Laporan Pembelian Barang Per Periode 


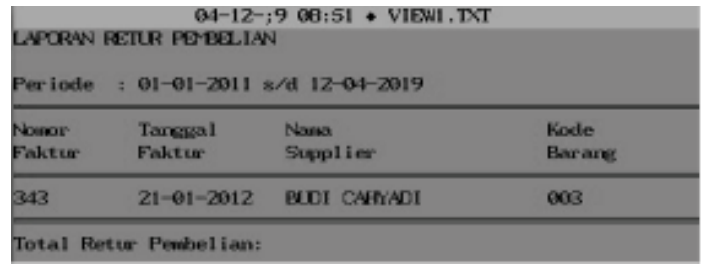

Gambar 22. Laporan Retur Pembelian Barang Per Periode

\begin{tabular}{|c|c|c|c|}
\hline \multicolumn{4}{|c|}{ LFORAN RETUR PENULALAN } \\
\hline $\begin{array}{l}\text { Whor } \\
\text { Wet. }\end{array}$ & $\begin{array}{l}\text { Tankakal } \\
\text { Nota }\end{array}$ & $\begin{array}{l}\text { Nowas } \\
\text { Ciextronex: }\end{array}$ & $\begin{array}{l}\text { Kode } \\
\text { Rarares }\end{array}$ \\
\hline $\begin{array}{l}70001 \\
100002\end{array}$ & $\begin{array}{l}21-01-2012 \\
29-05-2019\end{array}$ & $\begin{array}{l}\text { CASH } \\
\text { Ju.in }\end{array}$ & $\begin{array}{l}003 \\
001\end{array}$ \\
\hline
\end{tabular}

Gambar 23. Laporan Retur Penjualan Barang Per Periode

Untuk Laporan Pembelian dan Penjualan Barang serta Laporan Retur Pembelian dan Penjualan Barang (Gambar 20-23), pengguna sistem dapat mencetak laporan tersebut per periode seperti halnya Laporan Mutasi Barang.

\section{d. Menu Peralatan}

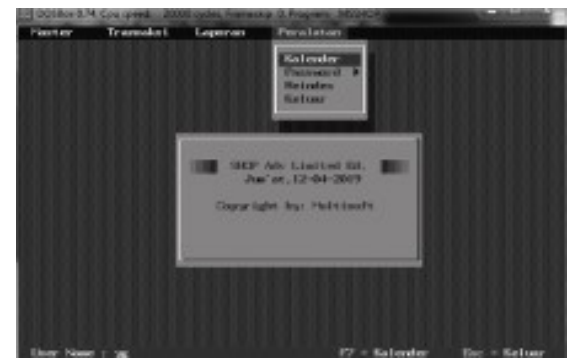

Gambar 24. Tampilan Menu Peralatan

Menu Peralatan (Gambar 24) merupakan menu tambahan yang berisi fitur-fitur yang mendukung jalannya program sistem persediaan ini. Sub Menu yang terdapat pada Menu Peralatan meliputi kalender (Gambar 25), menambah dan mengubah password (Gambar 26-27), mencari info password pengguna (Gambar 28), serta sub menu untuk keluar dari program.

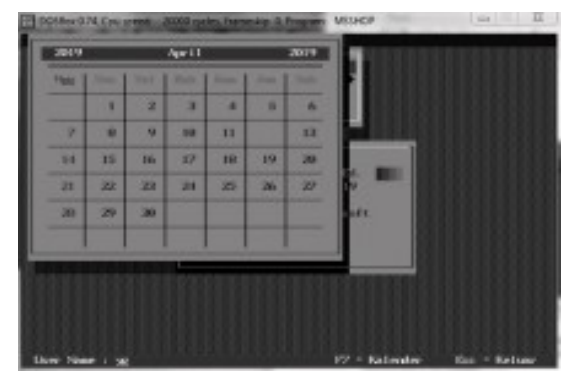

Gambar 25. Tampilan Kalender

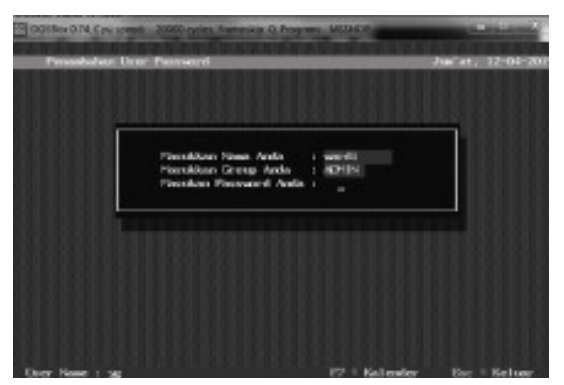

Gambar 26. Sub Menu Menambah Password

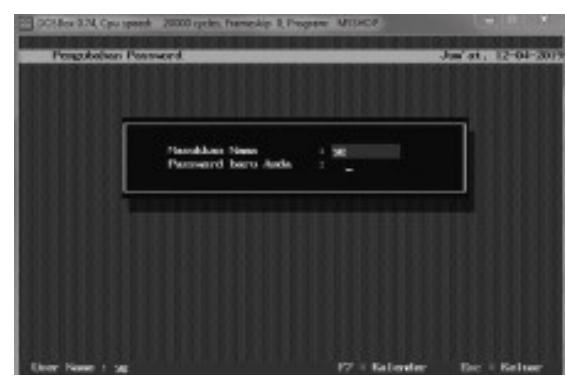

Gambar 27. Sub Menu Mengubah Password

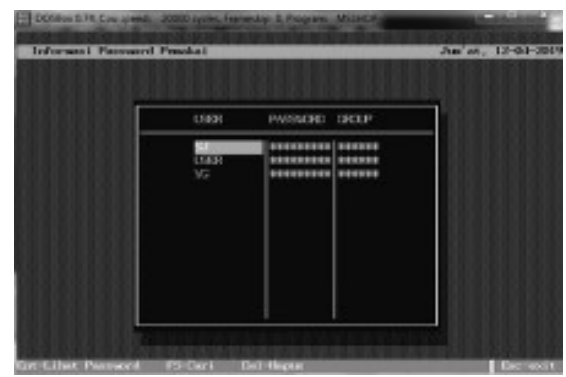

Gambar 28. Sub Menu Info Password Pengguna

\section{KESIMPULAN DAN SARAN}

\section{a. Kesimpulan}

1. Aplikasi sistem informasi persediaan oli ini dapat diterapkan secara efektif guna menunjang kegiatan operasional perusahaan di CV. Sumber Lumas Semarang.

2. Penggunaan sistem informasi persediaan oli ini membantu pihak manajemen CV. Sumber Lumas Semarang dalam menentukan kapan dan berapa jumlah oli yang harus dipesan dan tersedia di gudang sehingga persediaan oli tidak overstock/stock out.

3. Sistem informasi persediaan oli ini membantu pihak manajemen $\mathrm{CV}$. Sumber Lumas Semarang dalam menyediakan laporan persediaan oli yang akan digunakan oleh pihak manajemen sebagai dasar dalam 
pengambilan keputusan yang tepat dan akurat.

b. Saran

1. Untuk penelitian di masa yang akan datang, diharapkan aplikasi sistem informasi persediaan oli ini dapat dikembangkan menjadi sistem informasi akuntansi persediaan oli sehingga dapat membantu pihak manajemen dalam menyajikan laporan keuangan yang berkaitan dengan persediaan barang dagang.

2. Untuk penelitian di masa yang akan datang, diharapkan aplikasi sistem informasi persediaan oli ini dapat berbasis web dan dikembangkan dengan aplikasi Accurate dimana aplikasi ini mampu menginput data secara otomatis dan dapat mempermudah perusahaan dalam penginputan datanya (Juliana dan Wijaya, 2018).

\section{DAFTAR PUSTAKA}

Jogiyanto H.M., 2001, Analisis dan Desain Sistem Informasi, Yogyakarta: Andi Offset.

Krismiaji, 2015, Sistem Informasi Akuntansi, Edisi 4, Yogyakarta: UPP STIM YKPN.

Mulyadi, 2001, Sistem Akuntansi, Jakarta: Salemba Empat.

Ramdhany, Tri dan Kurnia, Deni, 2016, Perancangan Sistem Informasi Persediaan Barang Dagang Di PT. Dimarco Mitra Utama Cabang Bandung, Jurnal Rekayasa Sistem \& Industri, Volume 3, Nomor 1, Januari 2016.

Salim, Juliana dan Wijaya, Trisnadi, 2018, Analisis Sistem Informasi Akuntansi Persediaan Barang Dagang Pada PT. Autochem Industry Cab. Palembang, eprints.mdp.ac.id/2284/ (diakses 21 Januari 2019).

Stevenson, W.J dan Chuong, S.C., 2014, Manajemen Operasi Perspektif Asia, Edisi 9, Jakarta: Salemba Empat dan Mc. Graw Hill Education. 